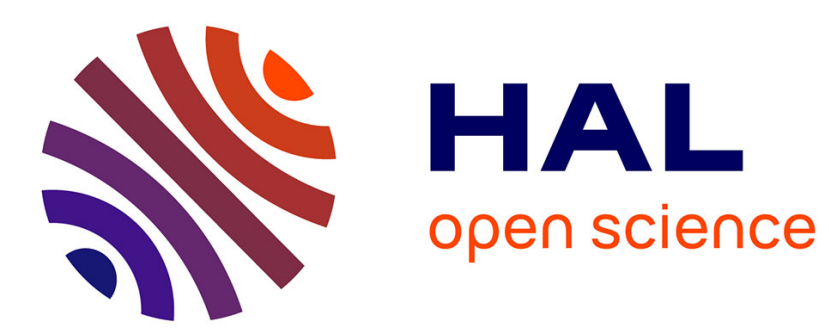

\title{
Mass media framing of biotechnology news
}

Leonie A. Marks, Nicholas Kalaitzandonakes, Lee Wilkins, Ludmila Zakharova

\section{To cite this version:}

Leonie A. Marks, Nicholas Kalaitzandonakes, Lee Wilkins, Ludmila Zakharova. Mass media framing of biotechnology news. Public Understanding of Science, 2007, 16 (2), pp.183-203. 10.1177/0963662506065054 . hal-00571095

\section{HAL Id: hal-00571095 \\ https://hal.science/hal-00571095}

Submitted on 1 Mar 2011

HAL is a multi-disciplinary open access archive for the deposit and dissemination of scientific research documents, whether they are published or not. The documents may come from teaching and research institutions in France or abroad, or from public or private research centers.
L'archive ouverte pluridisciplinaire $\mathbf{H A L}$, est destinée au dépôt et à la diffusion de documents scientifiques de niveau recherche, publiés ou non, émanant des établissements d'enseignement et de recherche français ou étrangers, des laboratoires publics ou privés. 


\title{
Mass media framing of biotechnology news
}

\author{
Leonie A. Marks, Nicholas Kalaitzandonakes, Lee Wilkins and Ludmila \\ Zakharova
}

In fast-changing scientific fields like biotechnology, new information and discoveries should influence the balance of risks and rewards and their associated media coverage. This study investigates how reporters interpret and report such information and, in turn, whether they frame the public debate about biotechnology. Mass media coverage of medical and agricultural biotechnology is compared over a 12-year period and in two different countries: the United States and the United Kingdom. We examine whether media have consistently chosen to emphasize the potential risks over the benefits of these applications, or vice versa, and what information might drive any relevant changes in such frames. We find that the two sets of technologies have been framed differently-more positive for medical applications, more negative for agricultural biotechnology. This result holds over time and across different geographic locations. We also find that international events influence media coverage but have been locally framed. This local newsworthiness extends to both medical and agricultural applications. We conclude that such coverage could have led to differences in public perception of the two sets of technology: more negative (or ambivalent) for agricultural, positive for medical applications. Our findings suggest that understanding news frames, and the events that drive them, provides some insight into the long-term formation of public opinion as influenced by news coverage.

\section{Introduction}

Few technologies have received as much news coverage as biotechnology. There are many applications but two-medical and agricultural-have seen more attention. There is some evidence that news media have been ambivalent about agricultural biotechnology and more positive towards medical applications. Public attitudes towards agricultural and medical biotechnology have seemed to mirror the news media's stance. Certainly, publics have been skeptical of biotechnology's use in agriculture. ${ }^{1}$ In contrast, opinion polls regarding medical biotechnology applications are globally more positive. ${ }^{2}$ Some have observed that perceptions and attitudes about biotechnology might have been cultivated by media framing of its relative risks and benefits: positive for medical, more negative for agriculture (Bauer, 2002). A review of the literature does suggest a negative media view of agricultural biotechnology. Such a view, however, has not been stable over time-positive early on, and more negative during the 
late 1990s (Priest and Talbert, 1994; Abbott and Lucht, 2000; Bauer, 2002; Bonfadelli et al., 2002; Marks et al., 2002, 2003). The media coverage of medical biotechnology has not been analyzed as extensively, though a small number of studies seem to suggest more positive views (Bauer, 2002; Pfund and Hofstadter, 1981; Conrad, 1999).

We expect that in new and fast-changing scientific fields like biotechnology, new information and discoveries would influence the balance of risks and rewards and their associated media coverage. How then are such new discoveries and information used by the mass media? Do reporters choose to emphasize more potential risks than potential benefits? Do they choose to emphasize risks over benefits for certain applications over others? Do they interpret and report differently information and thereby frame the public debate?

This study addresses these questions by comparing mass media coverage of the two sets of biotechnology applications-medical and agricultural-over a 12-year period and in two different countries - the US and the UK. In this context, we examine whether media have consistently chosen to emphasize the potential risks over the benefits of these applications, or vice versa, and what information might drive any relevant changes in such frames.

\section{Can media shape public perceptions and attitudes toward biotechnology?}

In many countries, the news serves as a primary source of risk communication to the general public (Boholm, 1998). The news media may define the agenda of public concern about a potential hazard. This process of mediated public attention is known as "agenda setting," or the concept that the media may not tell us what to think, but they tell us what to think about (McCombs and Shaw, 1972: 177; Cohen, 1963: 13). The core theoretical assertion of agenda setting theory is that the degree of emphasis placed on issues in the mass media adds salience to such issues and influences the priority accorded them by the public (McCombs and Ghanem, 2001: 67). Hence, the greater the volume and prominence of media coverage the more important the public will evaluate the issue to be. Entman (1991) alternatively refers to this process of the media lending overall salience to an issue as "sizing": how much material is available and how prominently it is displayed creates its importance. Issue salience or sizing has been the focus of empirical examination in multiple cultures for the past 30 years and has been found to apply to a variety of issues, including political campaigns and candidate selection, public opinion about drugs and crime, and even about competing brands of goods (Entman, 1991).

Developing in parallel with agenda setting theory is the idea that mass media not only lend salience to an issue but frame the discussion around it. Tuchman $(1976,1978)$ has argued that in reporting a story, journalists turn an occurrence into a newsworthy event, and a newsworthy event into a story, which is then communicated to the public. Journalists and editors employ frames according to their own understanding, while conforming to practical limitations such as deadlines and space (Hornig, 1990). Writing on science and technology can thus emphasize scientific facts, their sociopolitical implications, environmental risks, human health concerns, and so on (Hornig, 1990). Through frames, media highlight certain points of view and marginalize others, defining occurrences, and explaining how they are to be understood (Hornig, 1993). A technology's potential risk to the environment can be highlighted, while its potential economic benefits might be ignored, or vice versa, depending upon the story frame. In general, framing theory has not explicitly linked frames with opinion formation (McCombs and Ghanem, 2001).

Several scholars argue that the convergence of agenda setting and framing theories can yield a greater unity in our knowledge of how the media's picture of the world is constructed. 
These scholars (Lopez-Escobar et al., 1998; Kiousis et al., 1999; Golan and Wanta, 2001; McCombs and Ghanem, 2001) suggest a framing effect whereby attribute salience is transmitted to the public. Attributes may be defined as cognitive-concrete information about a particular political candidate's stand on specific issues for example—or affective, whether a particular question is reported in a positive or negative light. It is this framing process that these scholars suggest might ultimately influence public perception (McCombs and Ghanem, 2001). How risks are framed can include elements of both cognitive and affective attributes.

Entman (1991: 7) argues that such frames can be detected by probing for particular words and visual images that consistently appear in a narrative, and which convey thematically consonant meanings across media and time. He further argues that by providing, repeating, and, therefore, reinforcing words that reference certain ideas but not others, frames work to make some ideas more salient in the text, others less so and some invisible. Such repetition of words and images renders one interpretation that is more readily discernible, comprehensible, and memorable than others.

If risks are emphasized relative to the benefits of a technology, the theory predicts a more negative sentiment on the part of the public. Yet, it is not only how much risks are emphasized that influences public perceptions, but also how they are presented. Studies have shown that most risks can be grouped in terms of the degree to which a risk is "dreaded" and the degree to which a risk is "unknown" (Slovic, 2001). Findings in cognitive psychology suggest that people have a tendency to overestimate unusual and spectacular risks (such as bovine spongiform encephalopathy, tornadoes, and floods) and underestimate familiar ones, such as cancer, strokes and heart disease. Hazards that are more dramatic and spectacular may be more easily remembered and their higher cognitive availability explains the tendency of subjects to overrate the risks of such hazards (Kahneman and Tversky, 1984). Hence, the way risks are framed can influence how the public might remember them and respond.

\section{Biotechnology in the news}

So how have media covered biotechnology? A number of studies have investigated media coverage of biotechnology applications - mainly agricultural ones. Some observers argue that media have been sensationalistic or outright anti-technology in their reporting. For instance, Hoban (1995) noted that the mass media have been selective in their coverage of agricultural biotechnology, more interested in politics than science, simplicity rather than complexity, and danger rather than safety. It is possible, but such a hypothesis has not been demonstrated in media studies. What does seem clear is that coverage of agricultural biotechnology has been ambivalent rather than overly negative. Hagedorn and Allender-Hagedorn (1997) examined media coverage of agricultural biotechnology (microbes, modified plants, animals and foods) from 1987 to 1994 . They found that the popular press did focus more on "social" risks associated with biotechnology: health and ethical issues; value, nutrition, safety and labeling of biotech foods; public safety and regulatory input.

Abbott and Lucht (2000) examined US and UK media coverage of agricultural biotechnology from 1997 to 2000 . They found that reporting was initially positive but turned negative during the peak in media coverage in 1999. Frewer et al. (2002) investigated the effect of increased media reporting of biotech foods from 1998 to 2000 on public attitudes. They did not explicitly quantify frames employed, however. ${ }^{3}$ Marks et al. $(2002,2003)$ examined media frames of genetically modified crops in US and UK newspapers, finding that environmental 
risks (e.g., "irreversible transgenes") were emphasized over benefits (e.g., less pesticide use and associated benefits to water quality, land savings, less impact on wildlife). Bonfadelli et al. (2002: 118) found balanced to somewhat negative reporting of agricultural biotechnology in Swiss newspapers from 1997 to 1999: 25 percent of articles reported risks only, 25 percent both the risks and benefits, 21 percent benefits only, and 29 percent neither risks nor benefits. Scientists, the most frequently sourced group (43 percent of all articles), held positions on both sides of the technology (p. 119).

In contrast, Pfund and Hofstadter (1981) found that industrial rather than academic interests set the terms of discussion in media coverage of "recombinant DNA" (medical) in the late 1970s, implying more positive framing of biotechnology news. ${ }^{4}$ Priest and Talbert (1994) found that over 70 percent of biotechnology (both medical and agricultural) sources used were experts (either industry or scientists) in the early 1990s and framing was generally more positive. ${ }^{5}$ In reporting of genetics (medical) news in several US newspapers, Conrad (1999: 294) found that 49 percent to 80 percent of sources used were expert scientists. Conrad (1999) argues that the initial source for many science news stories is the principal author of a breaking journal article published in elite scientific journals. Moreover, some science reporters may assume that a particular scientific finding does not require "balance" because science has already gone through a peer-review process (Conrad, 1999). From this viewpoint, one might expect more positive framing in reporting of medical biotechnology. ${ }^{6}$

Bauer (2002) is the only study, that we are aware of, that has systematically compared reporting of agricultural and medical applications of biotechnology over an extended time period. He investigated media coverage in the UK press from 1973 to 1999 . He used four frames: prospect, concern, fait accompli, and the degree of risk-benefit. He also found more positive framing of biotechnology applications in UK media during the 1970s and 1980s and he concluded that the media cultivated an observed split in UK opinion-more positive for medical, negative for agricultural during the 1990s.

Clearly, some people have suggested that media have been (unduly) negative. However, empirical findings from biotechnology media studies suggest that the negative stance of the media has fluctuated over time: prior to the late 1990s some studies have documented a more positive framing of biotechnology applications including agricultural ones (Pfund and Hofstadter, 1981; Priest and Talbert, 1994; Bauer, 2002). However, later studies have shown that at the height of public debate, agricultural biotechnology coverage, at least, became more negative (Abbott and Lucht, 2000; Marks et al., 2002, 2003; Bauer, 2002). On the other hand, coverage has generally been more positive for medical applications. However, it is still unclear whether such focus is due to an undue emphasis on agbiotech potential risks or lack of attention on potential benefits. Do reporters choose to frame agricultural and medical biotechnologies differently? How is such potential framing related to new information that becomes available on these technologies over time?

\section{Research design}

With an emerging scientific technology one should expect new information to become available which could potentially alter the agenda. Such information might be of various kinds: major discoveries and technological milestones; commercialization experiences; new regulations or changes to existing regulations; or possible previously unknown risks or benefits revealed by a credible source. The risk-benefit ratio employed in coverage could be altered by such information. For example, as a technology is commercialized its actual benefits 
may become more clear; regulatory and other rules of conduct could be broken revealing unforeseen risks (e.g., Starlink). Major institutional changes, for example, mandatory labeling of the technology, could also signal an informational change and therefore a change in the risk-benefit ratio. All such events would enhance information and knowledge. Such events not only could give a reason for increased coverage but, importantly, could change the way risks and benefits are framed.

In order to examine empirically what might explain volume and potential changes in the risk-benefit ratio in biotechnology reporting in this study we record how such risk-benefit ratios are framed over a 12-year period. A longitudinal study of framing effects captures the dynamic "frame-changing" process of news coverage whereby the media can reframe the discussion of a public issue over its lifespan (Chyi and McCombs, 2004: 22). ${ }^{7}$ We then examine the relationship of how the flow of new information has affected the volume and risk-benefit ratio of such coverage. Coverage is compared across two different countries: the United Kingdom and the United States. We examine coverage in UK and US media given their recent differing experiences with the technology. ${ }^{8}$ While cross-country analyses are difficult to conduct (Livingston, 2003) they can nevertheless yield important insights (i.e., detection of any similarities and/or differences) in media frames employed and possible agenda setting effects (Gurevitch, 1989; Blumler et al., 1992; Peter, 2003; Livingston, 2003). Indeed, as Gurevitch (1989) suggests such analyses can contribute to the expansion of data in order to make more solid generalizations; alternatively they can provide important counters based on naive assumptions of universality.

We also systematically compare coverage across the two different applications of biotechnology. As the same genetic engineering techniques underlie the various applications, of biotechnology (Jenkins, 1998), they present an opportunity to investigate media narratives about them, and how these might influence perceptions. In this way, any similarities and differences in media frames can be detected. As Entman (1991: 6) points out, unless narratives of similar phenomena are carefully compared, news frames can be difficult to detect fully and reliably. Such comparisons can reveal the way in which news frames help establish a "common sense" or widespread interpretation of events, or, in the case of this study, of complex technologies, such as biotechnology (Entman, 1991: 6).

In order to make meaningful comparisons among the two sets of biotechnology applications we chose three different medical applications to compare with agricultural coverage: human cloning, xenotransplantation, and gene therapy. To the extent that the literature documents that agricultural biotechnology is controversial, ${ }^{9}$ these applications were chosen as they have also been associated with some degree of controversy, albeit less so, and they therefore provide an opportunity to explicitly test whether reporters have been more or less balanced in their reporting of medical versus agricultural applications.

Human therapeutic cloning involves both potential benefits and risks. Possible benefits of cloning (animal, human cell) include the production of biopharmaceuticals (where cloned animals produce pharmaceuticals for the treatment of human diseases); preservation of endangered species (where rare animals could be saved from extinction); and production of "personalized" stem cells for treating diseases (e.g., when a suitable bone marrow donor cannot be found) (Marchione, 1998). Detractors have argued that human cloning would lead to "armies of cloned slaves" or the marketing of "perfect" children (Williams, 1998). Also, cloning presents possible health risks, for example, Dolly the sheep's telomeres were discovered to be old in September 1997, and subsequently there have been concerns about Dolly's early aging.

Gene therapy is an approach for treating disease by either modifying the expression of an individual's genes or correcting abnormal genes (American Society of Gene Therapy, 2000). 
Several genetic diseases are candidates for gene therapy including cardiovascular disease, cancer, and autoimmune and infectious diseases, such as AIDS and hepatitis. Possible risks of gene therapy include over-expression of a missing protein, causing harm to the patient; inflammation or immune reaction to the viral vector used to express the gene; and transmission of viral vectors from the patient to other humans and the environment (National Cancer Institute, 2000). And at the extreme it can result in fatality.

Xenotransplantation involves the use of animal organs or tissue transplants to replace human parts. Potential benefits of xenotransplantation include an alleviation of human donor organ shortages, and the production of cells and tissue to treat diseases. "Xenografts" are genetically modified to be more human-like in order to prevent hyperacute rejection of the organ by the human body. Risk is typically viewed on an individual basis during clinical trials. However, there are several other concerns, such as infection (spread of animal retroviruses to humans) (Institute of Medicine, 1996).

Agricultural biotechnology has been used to produce higher crop yields, and, hence lower cost of the food supply, plants that are naturally protected from disease and insects, and potentially more nutritious and better tasting foods. Potential environmental benefits include reduced pesticide use and employment of soil saving cropping methods. Perceived environmental risks include "uncontrollable" or "irreversible" escape of transgenes with potential consequences for biodiversity, wildlife, and ecosystems. Potential food safety risks include possible "allergic reactions" to modified proteins. Crops produced through biotechnology are already significant components of the US and international harvest-especially for some key commodities. These include soybeans, corn, cotton, canola, and papaya. Most biotech foods, such as herbicide-tolerant soy and Bt-corn are used in animal feeds and in the production of ingredients for processed food products. Hence, all four medical and agricultural applications have been associated with potential health risks and benefits for individuals and society as a whole. Individual risks from medical applications include "dreaded" health risks; as well as ethical and moral risks. Potential catastrophic health risks include the "unintended" introduction of viruses into the human population from xenotransplantation and gene therapy. Similarly, agricultural biotechnology has evoked the potential for "catastrophic" effects in wild populations and "dreaded" and "unknown" health risks for future generations.

\section{Analysis of media frames}

We employ content analysis to investigate possible risk-benefit frames. A comprehensive database of newspaper articles relating to medical and food applications of biotechnology, published in the London Times, the Sunday Times and the Washington Post, was developed from an exhaustive list of key-words. The Lexis Nexis and Factiva electronic databases were searched. We chose national daily newspapers comparable in circulation size. ${ }^{10}$ The search resulted in 750 articles pertaining to the three medical applications of biotechnology, and 1,251 articles relating to agrobiotechnology coverage.

\section{Categorization and coding of the data}

We use Slovic's (1987) heuristic to identify reporting of "dreaded" risks versus the relative "benefits" of biotechnology. In order to operationalize dreaded risk, we utilized two categories of his psychometric model, namely, "catastrophic" and "memorable" risk. One variable resulted from these two factors, as risks can be either catastrophic or memorable or both. 
For example, Chernobyl was mentioned in media reports on agricultural biotechnology. Chernobyl is clearly a memorable event - it gained worldwide media coverage and attention, and is likely to be easily recalled by the general public. Likewise, Chernobyl has the connotation of being "catastrophic" to the general population in its immediate vicinity and to world populations and ecosystems. In most cases the two sets of risks overlap and were coded together. The Starlink food recall is considered a "memorable" but not a catastrophic risk event—given the minimal risk of allergic response attached to it by the US regulatory agencies and the Center for Disease Control (CDC). As we found that the majority of the codes in the dictionaries developed below indicated overlap between the two categories, they were combined into one variable.

Specific memorable risk events linked to agricultural applications include "Chernobyl," "Bhopal," the "Exxon Valdez," "Three Mile Island," "Times Beach," the "extinction of the Dodo," "the mad cow disaster," "dioxin scare," "Jack-in-the-Box scare," and so on. Memorable risk events linked with medical applications include reference to "Aldous Huxley," "Hitler," "holocaust," "eugenics," "Baby Fae," "Boys from Brazil," and so on. Catastrophic risks linked to both medical and agricultural coverage include phrases such as, "nightmarish," "calamitous," "catastrophic scenarios," "cause ecological disaster," "catastrophic for human health," "cause infectious epidemic," "cause extinction," "destroy the environment," "Pandora's box," "armies of clones," and so on.

All-inclusive categories of benefits were also developed for each of the applications. Agricultural biotechnology benefits were defined to include: health, environmental, economic, social, and humanitarian benefits associated with agrobiotechnology applications. Medical benefits were defined to include any type of disease that might be alleviated by the use of the medical intervention, more efficient techniques for detecting and treating disease, and more targeted and potent, cost-effective therapies for treating diseases.

\section{Coding scheme}

Both manual and electronic coding can be used to conduct content analysis. Electronic content analysis saves time, eliminates the need for multiple human coders, and accommodates large datasets. It offers more flexibility to investigators because dictionaries can be more easily modified and reapplied to the same texts. It also provides greater reliability because it removes human errors due to fatigue or changes in understanding of coding rules. However, if a category is complex, wide-ranging, and inclusive then manual coding may be necessary (Lee, 1997). Because of our sample size, we used computer-aided analysis to quantify the variables under study.

In developing the dictionaries, we used a two-step procedure. Two human coders manually coded a stratified random sample of articles $(n=127)^{11}$ from the entire population of articles. This approach allowed the researchers to test the reliability (consistency and validity) of the variable definitions. We use Krippendorf's alpha as a measure of reliability. This measure accounts for variation in interval and ratio level data. Common standards for what constitutes an acceptable level of agreement for intercoder reliability statistics are not in place (Neuendorf, 2002). Acceptable measures of agreement fall in the range of 0.70 to 0.90 (Krippendorf, 1970; Banerjee et al., 1999; Riffe et al., 1998). However, beyond-chance statistics, such as Krippendorf's alpha and Scott's PI, are afforded more liberal criteria than more simple measures (Neuendorf, 2002: 143). The initial level of agreement (Krippendorf's alpha) for the manual coding ranged from 0.73 to 0.91 for the benefits variables and 0.80 to 0.91 for the risk variables. 
The levels of agreement achieved by the two human coders were considered acceptable for further refinement of definitions and development of dictionaries of words and word phrases relating to the conceptual categories (measured by our operational definitions) that were constructed. Words "before" and "after" the word or phrase included in each category, or key-word-in-context (KWIC) analysis, were used. Development of the variables (dictionaries) involved an iterative process. ${ }^{12}$ Once the initial list of words and phrases had been developed, computer generated key-words-in-context lists were used to determine which words and phrases contained in the draft dictionaries were accurate indicators of the variable in question. Following the approach of Bengston and Xu (1995) and Marks et al. (2003), the dictionaries were refined until words or word phrases were used correctly 80 percent (or greater) of the time across the entire population of articles.

\section{Results}

\section{Frequency of coverage}

Figures 1 and 2 detail the coverage of the two applications by number of articles. Agricultural biotechnology received the most coverage in both newspapers from 1990 to 2001. However, it received far more attention in the UK than in the US during 1999 and 2000 as indicated by the spike in overall coverage. Medical coverage also increased during the 1990s. We find the height of public debate, as reflected in agricultural coverage, to be 1999 which was roughly four times that of medical coverage in the London Times and two times higher in the Washington Post.

\section{Differences in risk-benefit frames}

We find that international coverage of biotechnology has emphasized the agricultural risks significantly more than its medical ones. Tables 1 and 2 report frequencies of words or word phrases related to each variable by application. For the Washington Post, we find the proportion of benefits/risks is significantly higher, $\chi^{2}=135.61$ ( $\left.1 \mathrm{df}, p>0.001\right)$, for medical coverage $(1.98: 1)$ than agbiotech coverage $(0.86: 1)$. This result is mirrored for the London Times,

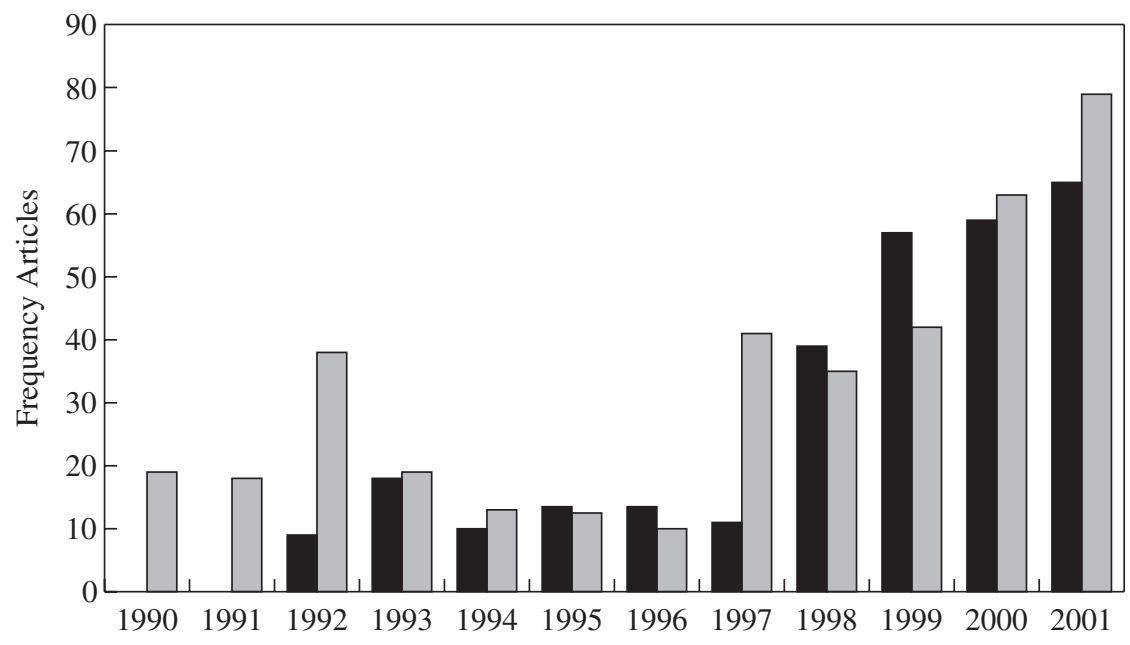

London Times $\square$ Washington Post

Figure 1. US and UK coverage of medical applications of biotechnology. 


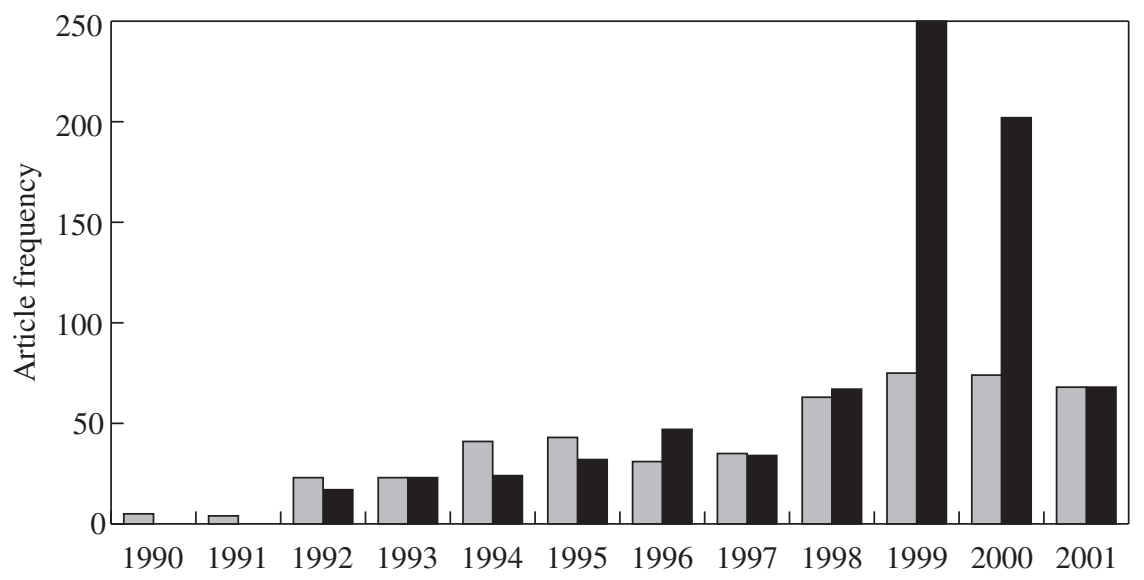

\section{Washington Post $\square$ London Times}

Figure 2. US and UK coverage of agricultural biotechnology.

Table 1. Washington Post coverage, 1990-2001

\begin{tabular}{lcc}
\hline Washington Post & $\begin{array}{c}\text { Benefits } \\
\text { (words / word phrases) }\end{array}$ & $\begin{array}{c}\text { Dread risks }^{\mathrm{a}} \\
\text { (words / word phrases) }\end{array}$ \\
\hline Agbiotech & $\mathbf{5 7 4}$ & $\mathbf{6 7 0}$ \\
Food safety & 429 & 426 \\
Environmental & 145 & 244 \\
Medical & $\mathbf{1 4 4 5}$ & $\mathbf{7 2 8}$ \\
Gene therapy & 671 & 480 \\
Human cloning & 594 & 159 \\
Xenotransplantation & 180 & 89 \\
\hline
\end{tabular}

a Dread risks refer to "catastrophic" risks and "memorable events" categories of the psychometric paradigm.

Table 2. London Times coverage, 1990-2001

\begin{tabular}{lcc}
\hline London Times & $\begin{array}{c}\text { Benefits } \\
\text { (words / word phrases) }\end{array}$ & $\begin{array}{c}\text { Dread Risks }^{\mathrm{a}} \\
\text { (words / word phrases) }\end{array}$ \\
\hline Agbiotech & $\mathbf{6 2 1}$ & $\mathbf{5 9 8}$ \\
Food Safety & 505 & 317 \\
Environmental & 116 & 281 \\
Medical & $\mathbf{1 2 5 3}$ & $\mathbf{3 0 9}$ \\
Gene therapy & 493 & 77 \\
Human cloning & 556 & 158 \\
Xenotransplantation & 204 & 74 \\
\hline
\end{tabular}

a Dread risks refer to "catastrophic" risks and "memorable events" categories of the psychometric paradigm. 
$\chi^{2}=266.98$ ( $\left.1 \mathrm{df}, p>0.001\right)$, with medical benefits exceeding risks (4.06:1), as opposed to agricultural biotechnology (1.04:1). Inter-country comparisons by application indicate that the Washington Post has generally been more negative than the London Times. In pairwise comparisons, the Washington Post emphasized the environmental and food safety risks of agricultural biotechnology more than the London Times did, $\chi^{2}=5.68$ ( $1 \mathrm{df}, p>0.017$ ) for the entire time period (1990-2001). The Washington Post was significantly more negative in its coverage of all medical applications taken together than the London Times was, $\chi^{2}=85.29$ $(1 \mathrm{df}, p>0.001) .{ }^{13}$ However, the two papers were not significantly different in their reporting of human cloning $\left(\chi^{2}=0.222,1 \mathrm{df}, p>0.637\right)$ and xenotransplantation $\left(\chi^{2}=2.733,1 \mathrm{df}, p>\right.$ 0.098 ) at a conventional level. Our findings support the overall negative framing of agrifood biotechnology that has been found in previous studies, and show strong positive framing of medical applications across the entire period. But how are such frames drawn by media? And how do they change over time in response to specific informational events?

\section{Framing of hazard events}

To answer these questions we examined how relevant informational milestones affected the cycle of coverage and framing (risk-benefit ratios) of the two sets of technology. A number of milestones may have influenced how reporters have covered stories of biotechnologies over time. We list such major commercialization and potential hazard events in Table 3. Recombinant bovine growth hormone (rBGH) was approved by the Food and Drug Administration in 1993 to increase the amount of milk produced by treated cows. Potential benefits of $\mathrm{rBGH}$ include an increase in the milk supply and a price reduction for consumers. However, cows treated with rBGH can produce milk with higher levels of insulin-like growth factor 1 (IGF-1). Insulin-like growth factor 1 , produced by humans as well as cows, plays a necessary role in many bodily functions. As a result, there were calls for mandatory labeling of dairy products from $\mathrm{rBGH}-$ treated cows. In 1994, Flavr Savr tomatoes were one of the first crops to be commercialized in the United States. Flavr Savr promised to be a new "designer crop" enhanced to improve taste and have a longer shelf-life. While Flavr Savr promised direct consumer benefits, potential risks of pollen transfer of foreign, implanted genes to wild plants or other crops were considered at the time of its introduction. In 1999, John Losey and colleagues published a laboratory study that indicated that monarch butterflies could be harmed by biotech corn pollen. Although the study's findings indicated only a potential hazard it indicated a potential and previously unanticipated risk and garnered international media attention. In May 2000, imported conventional canola seeds in the UK were found to contain some genetically modified (GM) seed that had not been approved for commercialization in European markets at the time. UK farmers unknowingly planted and multiplied them in their fields.

In the UK during 1998, Dr. Arpad Pusztai went on national television stating that biotech potatoes fed to laboratory rats had caused severe damage to their organs and overall development. While Dr. Pusztai's study was generally discredited by mainstream scientific societies, and his own research institute, it was subsequently published as a Research Letter in The Lancet (Ewen and Pusztai, 1999). In the United States, on the other hand, the commingling of the food supply with Starlink (a biotech corn feed approved for animal consumption only) led to recalls of multiple affected products. A highly reported fatality resulting from an experimental gene therapy trial took place in the United States in 1999-the case of Mr. Jesse Gelsinger. Dolly the sheep sparked controversy (over the possibility of human cloning) but also promised to deliver major benefits through the production of drugs manufactured by animals and from xenotransplantation. The Human Genome Project opened up vast potential for new 
Table 3. Biotechnology events (1990-2001)

\begin{tabular}{|c|c|c|c|}
\hline Event & $\begin{array}{l}\text { Dates of beginning } \\
\text { coverage }\end{array}$ & $\begin{array}{l}\text { Variable } \\
\text { name }\end{array}$ & Description \\
\hline $\begin{array}{l}\text { Bovine Growth } \\
\text { Hormone }\end{array}$ & January 1994 & BGH & $\begin{array}{l}\text { Bovine Growth Hormone (BGH) or rBST } \\
\text { approved and marketed in the United States }\end{array}$ \\
\hline Dolly the sheep & $\begin{array}{l}\text { February } 1997 \\
\text { June } 1997 \\
\text { September } 1997\end{array}$ & DOLLY & $\begin{array}{l}\text { Dolly is born } \\
\text { Human cloning banned in US } \\
\text { Dolly's telomeres are found to be old }\end{array}$ \\
\hline Flavr Savr tomato & April 1994 & FLAVR & $\begin{array}{l}\text { Flavr Savr tomato approved and marketed } \\
\text { in the United States }\end{array}$ \\
\hline GM Contamination & May 2000 & GMC & $\begin{array}{l}\text { UK imports of canola (rapeseed) found to } \\
\text { contain biotech seeds which farmers } \\
\text { planted unknowingly in their fields }\end{array}$ \\
\hline $\begin{array}{l}\text { Human Genome } \\
\text { Project }\end{array}$ & April 2000 & HGP & $\begin{array}{l}\text { Human genome mapped garnering worldwide } \\
\text { attention and commercial optimism }\end{array}$ \\
\hline Monarch butterfly & May 1999 & MON & $\begin{array}{l}\text { John Losey et al. publish lab study results } \\
\text { indicating monarch butterflies are } \\
\text { harmed by GM corn pollen }\end{array}$ \\
\hline $\begin{array}{l}\text { Philadelphia } \\
\text { experiment }\end{array}$ & September 1999 & GTEXP & $\begin{array}{l}\text { Mr Jesse Gelsinger dies from controversial } \\
\text { experimental gene therapy conducted at } \\
\text { University of Pennsylvania, Philadelphia }\end{array}$ \\
\hline Pusztai report & August 1998 & PUS & $\begin{array}{l}\text { Dr Arpad Pusztai goes on UK national } \\
\text { television saying that GM potatoes fed to lab } \\
\text { rats caused serious harm to their organs } \\
\text { and health }\end{array}$ \\
\hline Starlink & September 2000 & STAR & $\begin{array}{l}\text { US food supply commingled with Starlink } \\
\text { corn approved for use in animal feed only }\end{array}$ \\
\hline
\end{tabular}

discoveries in human health and agricultural production, but also highlighted the potential for individual risks (e.g., "inappropriate" use of genetic information by insurance companies).

\section{Regression analysis}

We examined the relationship between framing of potential hazard events and the aforementioned informational milestones through regression analysis. The effects of these events on reporters' frames are modeled through a system of seemingly unrelated regressions (SUR) given that the error terms may be correlated across newspapers and, therefore, estimation efficiencies are possible. We use generalized least squares estimation correcting for first-order autocorrelation where detected. Our empirical model is as follows:

$$
\begin{aligned}
D I F_{i}= & \alpha_{i}+\beta_{1 i} * M O N+\beta_{2 i} * G M C+\beta_{3 i} * P U S+\beta_{4 i} * S T A R+\beta_{5 i} * B G H+ \\
& \beta_{6 i} * F L A V R+\beta_{7 i} * D O L L Y+\beta_{8 i} * H G P+\beta_{9 i} * G T E X P+\beta_{10 i} * T I M E+\mu_{i}
\end{aligned}
$$

where MON, GMC, PUS, STAR, BGH, FLAVR, DOLLY, HGP, and GTEXP represent (predetermined) event variables related to the monarch butterfly (MON), the commingling of conventional canola seed with genetically modified seed (GMC), the report of Dr. Pusztai's study (PUS), the Starlink recall (STAR) in the United States, the introduction of bovine growth hormone (BGH) into the US milk supply from 1995 onwards, the brief introduction of the Flavr Savr tomato (FLAVR) into US markets in 1994, "Dolly the sheep" (DOLLY), the Human Genome Project (HGP) and the case of Mr. Jesse Gelsinger (GTEXP). Each event variable is measured by coverage in each newspaper. These event variables are regressed on the dependent 
variable $\mathrm{DIF}_{i}$ which measures absolute differences in reporting the benefits and risks of each application of the technology (medical and agricultural) in each (ith) newspaper, namely, the London Times (LT) and the Washington Post (WP). A time trend variable (TIME) is also included in each regression.

The empirical model is estimated using 144 consecutive months of data for each newspaper, with zeros substituted at the appropriate dates for non-existent coverage. This assumes that there is no qualitative difference between non-coverage and coverage where reporters chose not to report either risks or benefits associated with agricultural and medical applications of biotechnology. Some events were not covered by national newspapers. For example, in the case of agbiotech coverage the London Times did not run the Starlink story during the period of coverage (despite its international significance). Interestingly, other UK newspapers, such as the Guardian, the Financial Times, and the Independent did allocate space to Starlink.

\section{Results}

The results from two sets of regression models are reported in Table 4. The monarch butterfly event is associated with a strong risk frame in both countries. In this case, the original study by John Losey and colleagues was published in the prestigious journal Nature and was therefore highly newsworthy (Conrad, 1999; Mazur and Conant, 1978; Mazur, 1984, 1989; Singer and Endreny, 1993). Nevertheless, the monarch butterfly story was the only event that was framed in the same way across the two countries. The London Times reporting of the commingling of GM canola with conventional seed was also found to be negative-the commingling occurred at a time when debate was already heightened. Starlink was associated with an emphasis on the potential food risks of agricultural biotechnology, but only reported in the Washington Post, and other food safety events were mostly insignificant in explaining tone of coverage. For example, both the benefits and risks of biotechnology were equally reported during the "Pusztai affair"-effectively leading to balanced coverage in both countries. While some studies have concluded that the Pusztai affair sparked a more negative debate (Frewer et al., 2002), this is not reflected in our results. The research of Dr. Arpad Pusztai coincided with a significant increase in reporting of environmental benefits and risks in the London Times with an emphasis on benefits over risks. One possible explanation for this result, therefore, is that the work of Dr. Pusztai broadened the debate: proponents and opponents both aired their viewpoints in the media and the debate broadened to include other non-food safety issues, such as environmental ones (Marks et al., 2003).

FLAVR was significant in explaining a positive frame in agricultural coverage in the Washington Post. Hence, US reporters chose to emphasize the benefits and "potential" of new biotech foods with "enhanced taste and textures" over possible risks. DOLLY and the HGP were positively framed by London Times reporters in their coverage of medical biotechnology. On the other hand, DOLLY was covered with a more negative frame by Washington Post reporters reflecting the more contentious debate over human cloning that took place in the United States.

The fatality of Mr. Gelsinger did significantly influence reporting of the risks associated with gene therapy in the Washington Post explaining a large part of the variation. However, his death was framed as a local story and was not significant in explaining gene therapy coverage in the London Times. Only three out of 123 (2.4 percent) stories in the London Times mentioned Jesse Gelsinger, compared to 22 percent of gene therapy stories in the United States. 
Table 4. Effect of events on biotechnology reporting by country and newspaper.

\begin{tabular}{|c|c|c|c|c|}
\hline & \multicolumn{2}{|c|}{ Agbiotechnology } & \multicolumn{2}{|c|}{ Medical } \\
\hline & $\begin{array}{l}\text { London } \\
\text { Times }\end{array}$ & $\begin{array}{c}\text { Washington } \\
\text { Post }\end{array}$ & $\begin{array}{l}\text { London } \\
\text { Times }\end{array}$ & $\begin{array}{l}\text { Washington } \\
\text { Post }\end{array}$ \\
\hline Variable & LTAG_DIF & WPAG_DIF & LTMED_DIF & WPMED_DIF \\
\hline Intercept & $\begin{array}{l}-0.8827 \\
(-0.841)\end{array}$ & $\begin{array}{c}-0.817 \\
(-0.774)\end{array}$ & $\begin{array}{c}-0.366 \\
(-0.216)\end{array}$ & $\begin{array}{l}1.65 \\
(0.844)\end{array}$ \\
\hline MON & $\begin{array}{l}-1.397 \\
(-4.914)^{* * * *}\end{array}$ & $\begin{array}{l}-0.595 \\
(-3.532)^{* * * *}\end{array}$ & - & - \\
\hline GMC & $\begin{array}{l}-0.797 \\
(-4.721)^{* * * *}\end{array}$ & $\begin{array}{c}-2.038 \\
(-1.422)\end{array}$ & - & - \\
\hline PUS & $\begin{array}{c}-0.169 \\
(-1.141)\end{array}$ & $\begin{array}{l}2.25 \\
(1.951)\end{array}$ & - & - \\
\hline STAR & - & $\begin{array}{c}-1.028 \\
(-22.521)^{* * * *}\end{array}$ & - & - \\
\hline BGH & $\begin{array}{c}-0.571 \\
(-1.274)\end{array}$ & $\begin{array}{c}0.024 \\
(0.435)\end{array}$ & - & - \\
\hline FLAVR & $\begin{array}{c}-0.737 \\
(-0.881)\end{array}$ & $\begin{array}{l}0.623 \\
(2.131)^{* * *}\end{array}$ & - & - \\
\hline DOLLY & - & - & $\begin{array}{c}0.785 \\
(3.306)^{* * * *}\end{array}$ & $\begin{array}{c}-0.515 \\
(-2.01)^{* *}\end{array}$ \\
\hline HGP & - & - & $\begin{array}{c}2.865 \\
(2.861)^{* * * *}\end{array}$ & $\begin{array}{r}0.186 \\
(0.519)\end{array}$ \\
\hline GTEXP & - & - & $\begin{array}{l}-2.559 \\
(-0.73)\end{array}$ & $\begin{array}{l}-0.51^{\text {***** }} \\
(-6.52)\end{array}$ \\
\hline TIME & $\begin{array}{l}0.036 \\
(2.885)^{\text {**** }}\end{array}$ & $\begin{array}{l}0.039 \\
(2.902)^{\text {**** }}\end{array}$ & $\begin{array}{c}0.068 \\
(2.93)^{* * * * *}\end{array}$ & $\begin{array}{c}0.049 \\
(1.99)^{* *}\end{array}$ \\
\hline $\operatorname{AR}(1)$ & - & - & - & - \\
\hline Adjusted $\mathrm{R}^{2}$ & 0.27 & 0.79 & 0.25 & 0.22 \\
\hline DW statistic ${ }^{\mathrm{a}}$ & 1.93 & 1.72 & 1.84 & 2.21 \\
\hline
\end{tabular}

${ }^{a}$ DW statistic for untransformed model.

Notes: ${ }^{* *}$ statistical significance at $5 \%$, level; ${ }^{* * *}$ statistical significance at $1 \%$ level. Numbers in parentheses are $t$-values.

\section{Discussion and conclusions}

Risk perception is an important social and psychological phenomenon that influences decision-making at various levels of democratic societies. Understanding how the media have portrayed the relative risks and benefits of different applications of biotechnology is important to understanding how public perceptions are formed.

There are some interesting conclusions from our analysis. First, media have distinguished between different applications of biotechnology on the basis of its relative risk and benefit ratio that constitutes frames employing affective elements. In particular, medical applications of the technology have been portrayed more favorably than agricultural ones in mass media coverage across the two countries in this study. Media have highlighted the dreaded aspects of agricultural 
biotechnology more than those of medical coverage, a framing process that because it includes an affective component may influence public perception. Whether, in fact, such balance is justified on the basis of available evidence of harm is not so clear.

Second, while medical applications received much more favorable coverage, they have also received their share of controversy and public scrutiny. The death of Mr. Gelsinger strongly influenced reporting of gene therapy in the United States during 1999 and 2000. This was a newsworthy event that, as it turns out, had greater local significance. The reporting focused on an individual death and framed the risk from the individual point of view. Unlike coverage of agricultural biotechnology, news coverage about Mr. Gelsinger did not amplify the risk to all sorts of medical interventions with multiple populations. While the negative frame surrounding Mr. Gelsinger's death and its connection with gene therapy was not repeated in the UK, other applications of the technology, such as therapeutic human cloning, did not escape controversy either.

Human cloning generated considerable debate and international attention during 1997 when Dolly the sheep was first cloned. Subsequently, there was a call for an immediate ban on human cloning in the United States and stem cell research and its implications for the cloning of human embryos has been heavily debated since 2001. Priest (2001) notes that Dolly shifted the US debate about biotechnology to one that explicitly incorporated ethical considerations. We find that Dolly clearly sparked a more contentious debate in the United States. In contrast, in the United Kingdom, the cloning of human embryos for research purposes has been given the green light. Reporters in the UK (the country that developed the technology) took a more positive stance on Dolly. In other words, we find that the debate about Dolly, while internationally highly significant, was again locally framed.

Moreover, we find that Starlink, monarch butterfly, and GM canola all led to a more negative frame being employed. However, only in the case of the monarch butterfly was reporting consistently negative across the two countries. Once again the local focus in reporting is apparent. The London Times chose not to cover Starlink but the GM canola story was locally significant. Gene therapy coverage was strongly influenced by the gene therapy experiment in the United States only. On the other hand, the development of Flavr Savr tomatoes was positively framed in US media reports. Hence, it is the "local factor" (Singer and Endreny, 1993: 68 ) that makes specific biotechnology events more newsworthy. We find some support for the hypothesis of Galtung and Ruge (1965: 68): that is, the more an event concerns both nations, the more probable that it will become a news item, although this result is not universally supported. ${ }^{14}$ Instead, we find that the local factor turns into national rather than international framing of news events. This result is unexpected given an internationally conducted debate and increasingly global media (Livingston, 2003; Hachten, 2005).

Fourth, we find that information on potential risks and, particularly negative events (monarch butterfly, gene therapy experiment) drive frames. However, interestingly the very same event can be framed differently, in the case of Dolly. The local focus and selective use of the same information by reporters provides the strongest evidence yet that media can frame and might have actively framed agricultural and medical biotechnology, and the public debate through its coverage. It is of course difficult, and beyond the scope of this paper, to demonstrate that such reporting could have directly influenced public perception of agricultural and medical biotechnologies ${ }^{15}$ during the 1990s. However, some general inferences can be made. Figures 3 and 4 detail how public opinion of biotechnology has evolved over the time period investigated. These data are assembled from the Eurobarometer surveys conducted in 1991 to 2002 (EC, 1991, 1993, 1997, 2000, 2003) and from the International Food Information Council (IFIC, 2002) for the United States. The format of the questions varies slightly over the five surveys investigated for the UK case, ${ }^{16}$ and the 

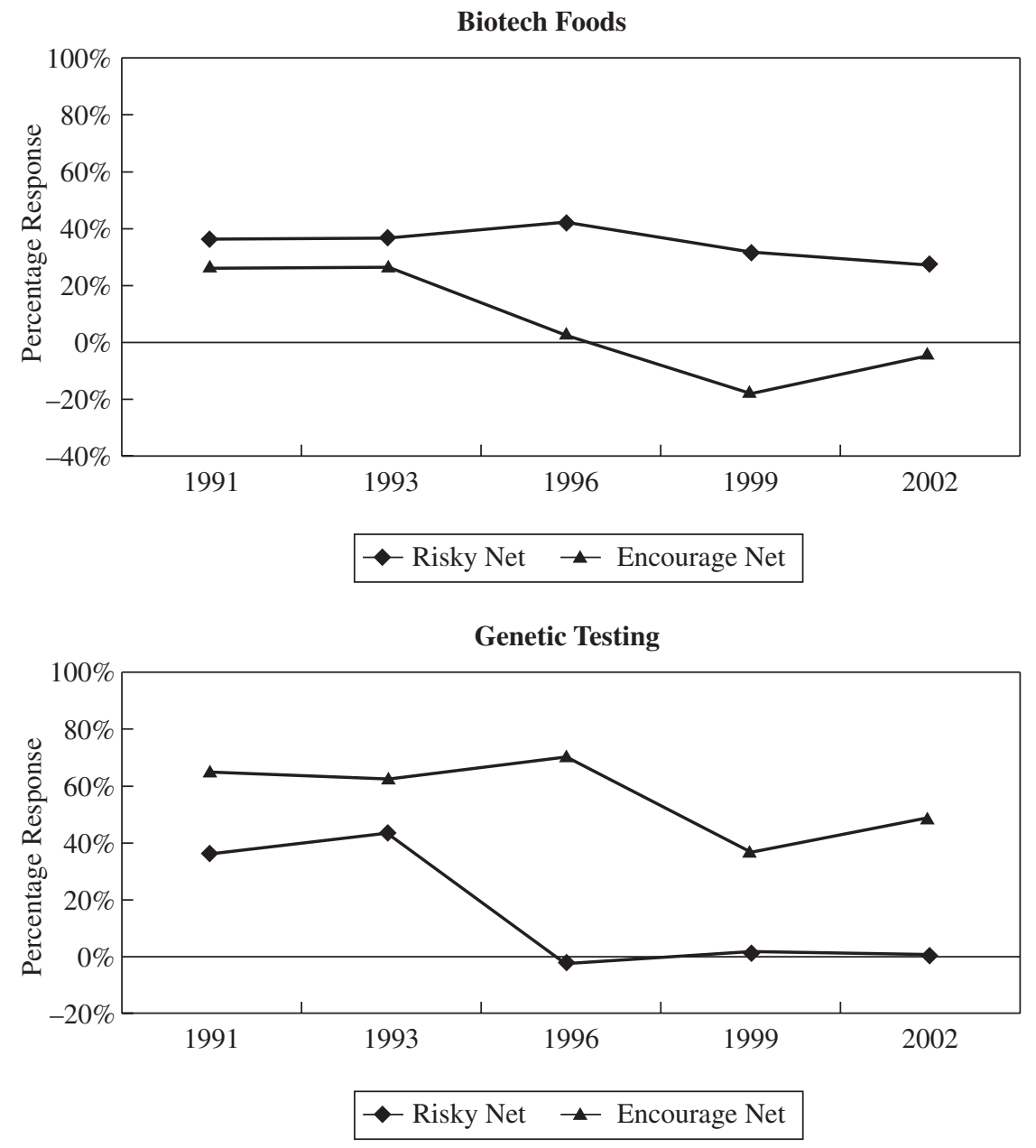

Figure 3. UK public opinion of biotechnology applications (1991 to 2002).

Note: Genetic testing question: "And what do you think of using genetic testing to detect diseases we might have inherited from our parents such as cystic fibrosis, mucoviscidosis, thalassaemia?" Biotech foods question: "Use of modern biotechnology in the production of foods, for example to make them higher in protein, keep longer or change the taste..." Possible responses are "agree," "somewhat agree," "disagree," "somewhat disagree," or "don't know" to whether "Such research is worthwhile and should be encouraged." Responses represented are "net," i.e., the degree to which the respondents agree with the statement minus the degree to which respondents disagree with the statement. Source: European Commission (1991, 1993, 1997, 2000, 2003), question format varies slightly by year.

correspondence of the medical and agricultural biotechnology covered in our study and their series is not complete. Nevertheless, Eurobarometer has consistently tracked public opinion of biotechnology used in genetic testing, crop production, foods and, to a lesser extent, vaccines. For brevity, we report opinion on genetic testing (proxy for medical) and biotech foods only.

From these series, changes in the volume and tone of agricultural biotechnology coverage in the London Times coincide with a negative shift in UK public opinion. Similarly, a 
(a)

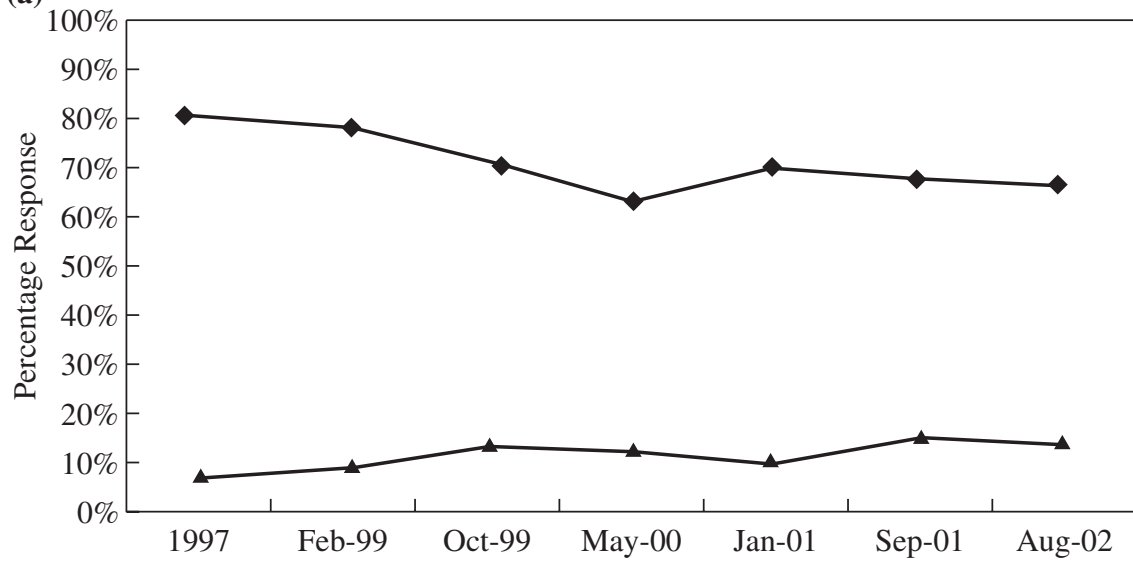

Yes $\quad \longrightarrow$ Don't know

(b)

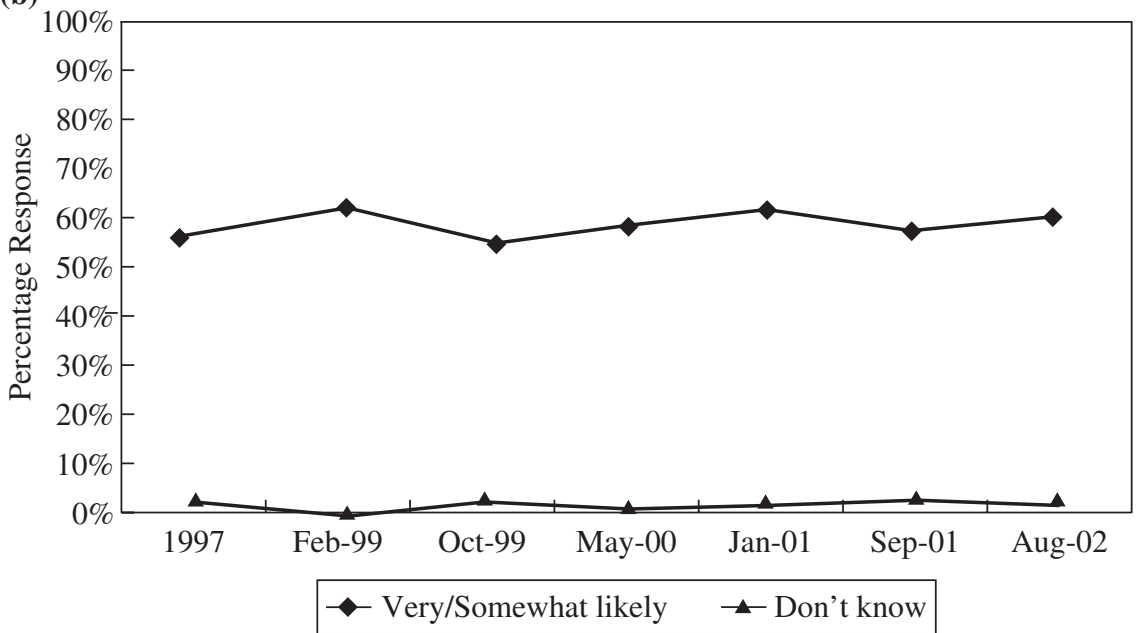

Figure 4. (a) US public opinion of biotechnology benefits (1997 to 2002) and (b) US public willingness to purchase biotech foods (1997 to 2002). Possible responses are "yes", "no" and "dont know".

Note: (a) Response based on the following question: "Do you feel biotechnology will provide benefits for you and your family within the next five years?" Source: IFIC (2002).

(b) Based on the following question: "All things being equal, how likely would you be to buy a variety of produce, like tomatoes or potatoes, if it had been modified by biotechnology to taste better or fresher? Would you be very likely, somewhat likely, not too likely, or not at all likely to buy these items?" Source: IFIC (2002).

more positive perception of medical biotechnologies than agricultural ones among the general public coincides with the strong positive framing of medical biotechnology during the 1990s (Figure 3). Volume of medical and agricultural coverage are both negatively correlated over time with US public opinion of biotechnology also. ${ }^{17}$ As usual, correlations do not necessarily imply causality but these aggregates suggest no inconsistencies in the hypothesis that 
media framing of biotechnology could have influenced public perception over the period of analysis.

In summary, we find that the two sets of technologies have been framed differently. This result holds over time and across different geographic locations. We also find that international events have been locally framed (for the most part). This local newsworthiness extends to both medical and agricultural applications. Similar to Bauer (2002) and Frewer et al. (2002) we also conclude that such coverage could have led to differences in public perception of the two sets of technology: more negative (or ambivalent) for agricultural, positive for medical applications. Public opinion formation and acceptance should not be reduced to a simple mirror of news reports. However, our findings suggest that understanding news frames, and the events that drive them, provides some insight into the long-term formation of public opinion as influenced by news coverage.

\section{Acknowledgements}

The authors acknowledge the helpful suggestions and comments of two anonymous referees. The authors are responsible for any remaining errors. This research was funded by the Illinois Missouri Biotechnology Alliance and, in part, supported by the Missouri Agricultural Experiment Station.

\section{Notes}

1 Support for biotech crops and foods has been slightly lower than for medical applications in US opinion polls (IFIC, 2002), and more so in Europe (European Commission, 1991, 1993, 1997, 2000, 2003). Several scholars have suggested public ambivalence towards biotech foods (Select Committee, 2003; Marris et al., 2001; Petts et al., 2001). Ambivalence is generally defined as "simultaneous and contradictory attitudes and feelings towards an object" (Webster's Collegiate Dictionary). By this definition, all applications of biotechnology exhibit some degree of ambivalence on the part of various publics. In opinion research it has been defined more narrowly to include a sub-group of respondents who "neither agree or disagree," or "have no opinion," on any given question asked (Select Committee, 2003). By this definition some European countries, such as the UK, have exhibited a higher level of ambivalence toward biotech foods than the US.

2 For example, in recent polls medical applications (vaccines, genetic testing) of biotechnology are typically twice as likely to be accepted in the United Kingdom (UK) as improved crop varieties or biotech foods (European Commission, 1991, 1993, 1997, 2000, 2003). The United States (US) has exhibited a similarly high level of support for human genetic screening (74-80\%) and new vaccines (80\%) (Hoban and Miller, 1998; Priest, 2000).

3 Their study focused on assessing the degree to which the mass media had amplified the risks associated with food biotechnology during the height of media coverage. Therefore, the focus of their data collection and analysis was three surveys conducted prior to the peak in UK coverage (February 1998), during the height of coverage (March 1999) and post-peak (July 2000). They conclude that perceptions of risk associated with biotech foods increased during the highest levels of reporting but were subsequently reduced as reporting levels diminished.

4 Pfund and Hofstadter (1981: 144) present data with the newspaper or magazine as the unit of measurement. Moreover, they quantify whether the newspaper or magazine included, "at least one mention of benefits and risks of recombinant DNA research" only. It is therefore difficult to definitively conclude the degree of positive or negative framing with such an aggregate approach.

5 Although Priest and Talbert (1994: 81) conclude that media coverage was predominantly positive in tone, the data presented on message content are not explicitly broken down by agricultural and medical applications.

6 However, Conrad did not explicitly code for positive (benefit) or negative (risk) messages so it is hard to conclude definitively.

7 Our coverage extends 2 years beyond the peak of public debate which occurred during 1999 in the United Kingdom. Reporting in subsequent years (2002-2005) is about one-third to one-half lower than in 1999.

8 Given opinion data suggest greater ambivalence on the part of the UK public towards agricultural applications of the technology, such a comparison allows for possible detection of differences (if any) in media reporting as a possible factor in the formation of such opinion. 
9 We define controversy to be a public dispute between two sides holding opposing views.

10 UK newspapers are highly differentiated. We therefore do not assume that the London Times coverage is necessarily representative of all UK newspapers. Similarly, for the United States.

11 Fifty articles are considered a minimum for reliable sub-samples (Neuendorf, 2002).

12 Phrases were developed as part of the manual coding exercise. These were incorporated as a baseline in our dictionaries. The dictionaries were further refined across the entire population of articles.

13 This finding is explained by a focus on the case of Mr. Jesse Gelsinger (discussed in the next section). However, a finding of more negativity on the part of Washington Post than London Times reporters is less expected. In other work, we have found the Washington Post to be more negative than other US newspapers in its coverage of agricultural biotechnology (Marks et al., 2002, 2003). Hence, caution is needed in generalizing beyond the newspapers analyzed here.

14 For example, the London Times chose not to report Starlink. Elsewhere, Marks et al. (2003: 11) document that the Daily Telegraph also chose not to run the Starlink story. However, other British newspapers did run the story including the Guardian, the Financial Times, and the Independent.

15 Our opinion data are stronger in the UK case: the different applications have been consistently tracked since the early 1990s. US opinion surveys are more fragmented and often the survey question does not delineate between medical and agricultural applications. Nevertheless, we use the IFIC (2002) tracking survey which has tracked opinion broadly on "biotechnology" and willingness to purchase biotech foods in particular.

16 For example, in the case of crop biotechnology, in 1991 and 1993 the question was asked in such a way as to introduce the application to respondents.

Scientists are trying to use biotechnology and genetic engineering to change plants, in ways that may be quicker than traditional programs, in order to make the plants more useful. For example, make these resistant to diseases or pests, make them ripen faster or give them the ability to grow in dry or salty soils. Please indicate to what extent you agree or disagree with each of the following statements concerning plant research. "Such research is worthwhile and should be encouraged." (EC, 1991, 1993)

By 1996 the format had changed slightly: "And what do you think of taking genes from plant species and transferring them into crop plants, to make them more resistant to insect pests? To what extent do you agree or disagree that this application [transferring genes from plants to crop plants] is risky for society?" (EC, 1997, 2000).

17 The available data for the US case are more problematic. The question regarding opinions of "biotechnology" may confound views of both applications. The question regarding agricultural biotechnology is "willingness to buy" rather than "support." Moreover, the IFIC opinion series runs from 1997 to 2003, only three data points in the media series.

\section{References}

Abbott, E. and Lucht, T. (2000) "How Triggering Events Affect Mass Media Coverage and Source Use Concerning Genetically Modified Organisms (GMOs) in Britain and the United States," Paper presented at the Agricultural Communicators in Education, USACC 2000 Congress, Washington DC.

American Society of Gene Therapy (ASGT) (2000) "Media Fact Sheet.” URL: http://www.asgt.org/press_releases /factsheet.html

Banerjee, M., Capozzoli, M., McSweeney, L. and Sinha, D. (1999) "Beyond Kappa: A Review of Interrater Agreement Measures," Canadian Journal of Statistics 27(1): 3-23.

Bauer, M.W. (2002) "Controversial Medical and Agri-food Biotechnology: A Cultivation Analysis," Public Understanding of Science 11: 93-111.

Bengston, D.N. and Xu, Z. (1995) “Changing National Forest Values: A Content Analysis,” Research Paper number NC 323. United States Department of Agriculture, Forest Service, North Central Forest Experiment Station, St. Paul, Minnesota.

Blumler, J.G., McLeod, J.M. and Rosengren, K.E. (1992) "An Introduction to Comparative Communication Research," in J.G. Blumler, J.M. McLeod and K.E. Rosengren (eds) Comparatively Speaking: Communication and Culture across Space and Time, pp. 3-18. Newbury Park, CA: SAGE.

Boholm, A. (1998) "Comparative Studies of Risk Perception: A Review of Twenty Years of Research," Journal of Risk Research 1(2): 135-63.

Bonfadelli, H., Dahinden, U. and Leonarz, M. (2002) "Biotechnology in Switzerland: High on the Public Agenda, but only Moderate Support," Public Understanding of Science 11: 113-30.

Chyi, H.I. and McCombs, M. (2004) "Media Salience and the Process of Framing: Coverage of the Columbine School Shootings," Journalism and Mass Communication Quarterly 81(1): 22-35. 
Cohen, B.C. (1963) The Press and Foreign Policy, p. 13. Princeton: Princeton University Press.

Conrad, P. (1999) "Uses of Expertise: Sources, Quotes, and Voice in the Reporting of Genetics in the News," Public Understanding of Science 8(4): 285-302.

Entman, R.M. (1991) "Framing U.S. Coverage of International News: Contrasts in Narratives of the KAL and Iran Incidents," Journal of Communication 41(4): 6-26.

European Commission (EC) (1991) "Public Transportation and Biotechnology," Eurobarometer 35(1). Brussels: The European Commission.

European Commission (EC) (1993) "Energy Policies, Biotechnology, and Genetic Engineering," Eurobarometer 39(1). Brussels: The European Commission.

European Commission (EC) (1997) "The Europeans and Modern Biotechnology," Eurobarometer 46(1). Brussels: The European Commission.

European Commission (EC) (2000) “The Europeans and Modern Biotechnology," Eurobarometer 52(1). Brussels: The European Commission.

European Commission (EC) (2003) "Europeans and Biotechnology in 2002," Eurobarometer 58(0). Brussels: The European Commission.

Ewen, S.W.B. and Pusztai, A. (1999) "Effects of Diets Containing Genetically Modified Potatoes Expressing Galanthus nivalis Lectin on Rat Small Intestine," Lancet 354(9187): 1353-4.

Frewer, L.J., Miles, S. and Marsh, R. (2002) "The Media and Genetically Modified Foods: Evidence in Support of Social Amplification of Risk," Risk Analysis 22(4): 701-11.

Galtung, J. and Ruge, M.H. (1965) “The Structure of Foreign News,” Journal of Peace Research 2(1): 64-91.

Golan, G. and Wanta, W. (2001) "Second-level Agenda Setting in the New Hampshire Primary: A Comparison of Coverage in Three Newspapers and Public Perceptions of Candidates," Journalism and Mass Communication Quarterly 78(2): 247-59.

Gurevitch, M. (1989) “Comparative Research on Television News," The American Behavioral 33(2): 221-9.

Hachten, W.A. (2005) The Troubles of Journalism: A Critical Look at What's Right and Wrong with the Press, 3rd edn. Mahwah, NJ: Lawrence Erlbaum Associates.

Hagedorn, C. and Allender-Hagedorn, S. (1997) "Issues in Agricultural and Environmental Biotechnology: Identifying and Comparing Biotechnology Issues from Public Opinion Surveys, the Popular Press and Technical/Regulatory Sources," Public Understanding of Science 6: 233-45.

Hoban, T.J. (1995) “The Construction of Food Biotechnology as a Social Issue," in D. Maurer and J. Sobal (eds) Eating Agendas: Food Nutrition as Social Problems, pp. 189-209. Hawthorne, NY: Aldine de Gruyter.

Hoban, T.J. and Miller, J.D. (1998) "Consumer Images and Impressions," Paper presented at the Annual Meetings of the American Association for the Advancement of Science, Philadelphia, PA.

Hornig, S. (1990) "Science Stories: Risk, Power, and Perceived Emphasis," Journalism Quarterly 67(4): 767-76.

Hornig, S. (1993) "Reading Risk: Public Response to Print Media Accounts of Technological Risk," Public Understanding of Science 2: 95-109.

Institute of Medicine (1996) Xenotransplantation: Science, Ethics and Public Policy, 136 pp. Washington DC: Committee on Xenograft Transplantation, Ethical Issues and Public Policy, Institute of Medicine.

International Food Information Council (IFIC) (2002) U.S. Consumer Attitudes toward Food Biotechnology. Washington DC: IFIC.

Jenkins, M. (1998) Genetics. Chicago, IL: NTC/Contemporary Publishing.

Kahneman, D. and Tversky, A. (1984) "Choices, Values, and Frames," American Psychologist 39(4): 341-50.

Kiousis, S., Bantimaroudis, P. and Ban, Hyun (1999) "Candidate Image Attributes: Experiments on the Substantive Dimension of Second Level Agenda Setting," Communication Research 26(4): 414-28.

Krippendorff, K. (1970) "Bivariate Agreement Coefficient for Reliability of Data," Sociological Methodology 2: 139-50.

Lee, D. (1997) "The Impact of Poor Performance on Risk-taking Attitudes: A Longitudinal Study with a PLS Causal Modeling Approach," Decision Sciences 28(1): 59-80.

Livingston, S. (2003) "On the Challenges of Cross-national Comparative Media Research," European Journal of Communication 18(4): 477-500.

Lopez-Escobar, E., Llamas, J.P. and McCombs, M. (1998) "Agenda Setting and Community Consensus: First and Second Level Effects," International Journal of Public Opinion Research 10: 355-63.

Losey, J.E., Rayor, L.S. and Carter, M.E. (1999) “Transgenic Pollen Harms Monarch Larvae,” Nature 399: 214.

McCombs, M.E. and Ghanem, S.I. (2001) “The Convergence of Agenda Setting and Framing," in S.D. Reese, O.H. Gandy and A.E. Grant (eds) Framing Public Life: Perspectives on Media and our Understanding of the Social World, pp. 67-81. Mahwah, NJ: Lawrence Erlbaum Associates.

McCombs, M.E. and Shaw, D.L. (1972) “The Agenda-setting Function in Mass Media," Public Opinion Quarterly 26: $176-87$. 
Marchione, M. (1998) “Cloning Research Could Offer Great Benefits, some Experts Say,” The Milwaukee Journal Sentinel 19 January, p. 1.

Marks, L.A., Kalaitzandonakes, N., Allison, K. and Zakharova, L. (2002) "Time Series Analysis of Risk Frames in Media Communication of Agrobiotechnology," in V. Santaniello, R.E. Evenson and D. Zilberman (eds) Market Development for Genetically Modified Agricultural Products, pp. 217-25. Wallingford, UK: CABI.

Marks, L.A., Kalaitzandonakes, N., Allison, K. and Zakharova, L. (2003) "Media Coverage of Agrobiotechnology: Did the Butterfly Have an Effect?," Journal of Agribusiness 21(1): 1-20.

Marris, C., Wynne, B., Simmons, P. and Weldon, S. (2001) "Public Perceptions of Agricultural Biotechnologies in Europe,” Final Report of PABE Research Project, FAIR CT98-3844 (DG12-SSMI), 62 pp. Brussels: The European Commission.

Mazur, A. (1984) "Media Influences on Public Attitudes toward Nuclear Power," in W.R. Freudenburg and E.A. Rosa (eds) Public Reactions to Nuclear Power: Are there Critical Masses?, pp. 97-114. Boulder CO: American Association for the Advancement of Science/Westview.

Mazur, A. (1989) "Communicating Risk in the Mass Media," in D.L. Peck (ed.) Psychological Effects of Hazardous Toxic Waste Disposal on Communities, pp. 119-37. Springfield, IL: Charles C. Thomas Publishers.

Mazur, A. and Conant, B. (1978) “Controversy over a Local Nuclear Waste Repository," Social Studies of Science 8(2): 235-43.

National Cancer Institute (2000) “Cancer Facts: Questions and Answers about Gene Therapy.” URL: http://cis.nci. nih.gov/fact/7_18.htm

Neuendorf, K.A. (2002) The Content Analysis Guidebook. Thousand Oaks, CA: SAGE.

Peter, J. (2003) "Country Characteristics as Contingent Conditions of Agenda Setting: The Moderating Influence of Polarized Elite Opinion," Communication Research 30(6): 683-712.

Petts, J., Horlick-Jones, T. and Murdock, G. (2001) "The Social Amplification of Risk: the Media and the Public," Contract Research Report 329/2001. Norwich: Her Majesty's Stationery Office.

Pfund, N. and Hofstadter, L. (1981) "Biomedical Innovation and the Press," Journal of Communication 31(2): 138-54.

Priest, S.H. (2000) “US Public Opinion Divided over Biotechnology,” Nature Biotechnology 18: 939-42.

Priest, S.H. (2001) A Grain of Truth: The Media, the Public and Biotechnology, p. 136. Lanham, MD: Rowman \& Littlefield.

Priest, S.H. and Talbert, J. (1994) "Mass Media and the Ultimate Technological Fix: Newspaper Coverage of Biotechnology," Southwestern Mass Communication Journal 10(1): 76-85.

Riffe, D., Lacy, S. and Fico, F.G. (1998) Analyzing Media Messages: Using Quantitative Content Analysis in Research. Mahwah, NJ: Lawrence Erlbaum Associates.

Select Committee on Environmental Audit Minutes of Evidence (2003) The United Kingdom Parliament, Examination of Witness, Questions 484-99, 17 December (testimony of Nick Pidgeon).

Singer, E. and Endreny, P.M. (1993) Reporting on Risk: How the Mass Media Portray Accidents, Diseases, Disasters and other Hazards. New York: Russell Sage.

Slovic, P. (1987) “Perceptions of Risk," Science 236(4799): 280-5.

Slovic, P. (2001) The Perception of Risk. Sterling, VA: Earthscan Publications.

Tuchman, G. (1976) "Telling Stories," Journal of Communication 26(4): 93-7.

Tuchman, G. (1978) Making News: A Study in the Construction of Reality. London: Collier Macmillan.

Williams, P.J. (1998) "I a Child, and Thou a Lamb (Impact on Humanity of Developments in Genetic Science)," The Nation 266(4): 8.

\section{Authors}

Leonie A. Marks is Associate Program Director in the Economics and Management of Agrobiotechnology Center (EMAC), Assistant Research Professor of Agribusiness, and Director of the MU Life Sciences and Society Program at the University of MissouriColumbia. Her research focuses on agrifood biotechnology innovation, consumer behavior and the role of information in consumer choice. Correspondence: 125D Mumford Hall, Columbia, MO 65211, USA; e-mail: Marksla@missouri.edu 
Nicholas Kalaitzandonakes is the MSMC Endowed Professor of Agribusiness and Director of the Economics and Management of Agrobiotechnology Center (EMAC) at the University of Missouri-Columbia. His research, teaching and outreach focus on the economics and policy of agrifood biotechnology and other agribusiness innovations.

Lee Wilkins is a Professor in the School of Journalism and the Harry S. Truman School of Public Affairs at the University of Missouri-Columbia. Her research interests include media ethics, risk communication and political communication.

Ludmila Zakharova is a Graduate Research Assistant in the Economics and Management of Agrobiotechnology Center at the University of Missouri-Columbia. Her research focuses on media communication of biotechnology news. 